\title{
Information and Communication Technology Integration on Human Rights Advocacy
}

\author{
Dr.K.M.Ashifa ${ }^{1}$ \\ ${ }^{1}$ Asst.Professor Department of Social Work Faculty of Health Science Istanbul Gelisim University. - Turkey \\ Article History: Received: 11 January 2021; Accepted: 27 February 2021; Published online: 5 April 2021
}

\begin{abstract}
The inalienable human rights codifications form the basis of human progress. "The goal of this document is to resolve a current and significant problem regarding the convergence of human rights advocacy and the role of ICTs. It will promote efforts to advocate, educate and communicate with others, including media and political stakeholders within and outside the human rights world"'[3]. The use of social media can consciously trigger the human rights movement and can also add to their outrage. Any public member or a human rights organisation sends the post, it is reasonably straightforward to explicitly concentrate public attention on social media. The present investigationtried to assess integration of online environment for human rights advocacy.

Keywords: Education, Advocacy, Human Rights, sustainability
\end{abstract}

\section{Introduction}

Inalienable codifications are human rights, which form the foundation for human progress. The "dignity and worth" of an individual is both a means of ending development[13]. The individual members of society became more civilized and more mindful of their rights. This increased understanding resulted in the formulation of unique behavioral styles, customs and rituals that would make man more protective and life more peaceful [1]. "The creation and full enjoyment of human rights is important for all people, for fostering an inspiring vision of a democratic, equal and prosperous world and for setting minimum standards for treating individuals and institutions and empowering people to take action to protect and defend their rights and the rights of others" [2]. "Human rights advocacy is more than just evidence; it is also about fostering societies which are friends of human rights and educated, and therefore open to advocacy" [5]. The ICT category includes all of the hardware and software that makes digital information creation, storage, transmission and receipt easier. The use of ICT provides a series of new opportunities and obstacles to human rights practice. Understanding the effect of innovation on human rights deficiency in ICT production and use [12]. This paper discusses a current and important problem concerning the convergence of the advocacy of human rights and the role of ICTs. The present investigation tried to assess integration of online environment for human rights advocacy.

\section{A conceptual Analysis}

"ICTs provide innovative strategies to pursue governance and advocacy objectives. However, the disclosure of detailed information on human rights and human rights organizations can jeopardize unique features and cultures" [12]. "People and their associations continue to use combinations of different tactics to accomplish their advocacy goals. Advocacy is an important part of professional development, including practices , procedures, experience and performance. It can be objected to change if both parties depend on the advocacy process" [3]. "ICT supports campaigns to advocate, inform and engage with others, including the media and stakeholders in and outside the human rights community. These incentivities, however, include the evaluation of authenticity and reliability on information that is communicated, the control of mass data sources, the avoidance or elimination of safety vulnerabilities and threats for human rights activists, and the battle against media wars aimed at distorting popular expression in a digital age" [8].

The ICT's goal is to recognize representatives, create relations, communicate resources and organize action through communities, organizations and coalitions. This allows elected leaders to consider options and at the same time freely involved people in the decision-making process[11]. ICTs are exploited by human rights groups to endorse and encourage the practices of particular connections and study opportunities. This includes the ability to easily, freely and interactively touch targets and to evaluate the success of messages as well as the sophistication and segmentation of the audiences[10]. "Social mobilization ICTs encourage their citizens to interact human rights institutions by circumventing the traditional but often inscrutable public communication networks of the mass media. This still-untested optimism has encouraged creativity through social media and other public relations resources in many lobbying activities" [17]. "Human Rights Organizations' expertise has been gained of using social media to easily and explicitly bind community members of their campaigns. Public engagement in a campaign is visible by social media, collections, re-tweets and other numerical measures. The level of participation, which is part of the help strategy itself, is also obvious as messages in social media applications are incorporated automatically using hashtags" [4]. 
Promoting individual awareness is a way to build a culture of human rights and protects abuses. "ICTs," including online tools, mobile apps and games[12], are developing new channels of knowledge on rights and protective steps. "The emphasis is on the provision of human rights education among other web resources in addition to this provision of data. International Centres for Human Rights give free online courses" [17]. Children's players are meant to teach human rights by playing. These programs are focused on "ICTs"' ability to analyze, communicate and even be portable. They help spread omnipresent ideas about human rights worldwide, but they would only be able to defend themselves if citizens on one side of the digital divide.

\section{Review of Literature}

"Advocacy is an attempt to change cause, concept or rule and slowly change behavior. This leads to increased visibility of network participants through meetings, social activities and public relations campaigns" [9]. "Advocacy is a mechanism that includes individuals or organizations that normally influence public policy and assign money to political , economic and social processes and structures that affect people's lives directly" [3]. "Advocacy has various forms. : Citizens advocacy is the one-to-one relationship with a trained, unpaid volunteer who is oppressed. Typically this is a long-term partnership. Registered employees with the skills will serve as advocates for professional or specialist activism. They tend to work in short term with residents as members of people. Collective self-defence means supporting the assembly and gaining power from a collective voice" [15]. "Advocacy has always been part of a registered practice for instilling human rights society in society, building capacity through its participation and networking, mobilizing capital, lobbying without neglecting transparency, changing policy, and changing public perception" [6]. "They can include numerous initiatives conducted by an person or an organization through publicity, promotion, mass awareness raising, commissioning, publication and dissemination of information. This contributes to a free society without violation which respects the value and dignity of the person and of the community" [14]. Advocacy is viewed as a primary intervention technique for adapting human rights principles and values to real life. A truly integrated culture with human rights can be accomplished through a mutually fulfilling process that enshrines the ideals in the everyday lives of its people [10]. Knowledge has become the foundation for secure, effective sustainable development and international relations. Given that information availability is subject to various communication networks, in recent years the knowledge society has developed new and creative ways to connect people[7]. ICT, the omega alpha that removes the quietness of society today. The report prepared by Ella McPherson (2015) on "ICTs and UN Special Rapporteur's Human Rights Practices" provides an informative overview of this topic. It offers a very general summary of ICT ramifications, emerging technology opportunities and the state's resources. This paper addresses problems surrounding human rights defenders and supporters who distribute unwanted knowledge from militant groups.

\section{Methodology}

The study mainly aims to explore the role of ICTs in the promotion of human rights in this digital age. In evaluating the problem of security of human rights with ICT, qualitative and quantitative methods were used for the most useful outcomes. Young people have made direct online observations and interviews on "social media ( Facebook, Twitter and YouTube)," and obtained data from available sources. Studies provide realistic aspects of circumstances by observing the movement of different online behaviors. Data were analyzed at the end of the observation point to establish relations with variables.

\section{Result and Discussion}

This study attempted to analyze the effects of IT on human rights protection. Seventy-two percent of young people on social media's most popular site said they were using Facebook like Instagram and Twitter. Most respondents who use the same tool to generate general awareness, express opinions on different issues and improve their career effectively. One query why websites should be used is for $60 \%$ of respondents to use social media sites to contact friends and relatives, for $15 \%$ to share social networks and for $10 \%$ for business networking. Online crime is cybercrime. Cybercrimes are of various kinds: hacking, theft of personal data and theft of documents. 60 percent say they are cyber-crime victims and $40 \%$ do not. Many respondents may therefore be said to be affected by cybercrime.

The young adult mostly uses social media to express his views on social issues. $58 \%$ of respondents believed that social media guaranteed freedom of speech. At the same time, $38 \%$ believed it was not so successful. Nearly $80 \%$ of respondents receive information from social media about human rights abusses and related issues. In this danger initiative, the majority $(88 \%)$ of respondents and $78 \%$ were lobbied by human rights defenders, social 
activists and NGOs. According to 83 percent of participants, social media helped them to increase their awareness of human rights and social security systems. Most of the respondents, i.e. $79 \%$, have a favorable opinion of the role of social media in defending human rights. Consequently, most respondents thought that the use of social media to communicate human rights cultures has a positive influence on society as well as a way to exchange opinions on critical and socially significant information.

\section{Conclusion}

This study now includes a review of ICT human rights interventions. In particular, ICTs provide new avenues to fast and mobilizing audiences, directly discussing 'advocacy goals' and raising questions about human rights. The use of social media may potentially contribute to the movement for human rights but also to the indignation of citizens. The problem is human rights activism, which turns movements into lobbying by growing social media proliferation. The power of social media to viralize and spread information will easily include human rights and the conventional protection of human rights. The theory is that virality is normally connected to messages of hope, optimism and excitement. There are threats to availability of pace in social media that is based on virality. Errors harm the reputation of "human rights organizations" and thus weaken their "advocacy"' effectiveness.

\section{Reference}

1. Abdi, A. A., \& Schultz, L, "Educating for Human Rights Global Citizenship", State University of New York,2008.

2. Agarwal, H, "Human Rights". Central Law, 2004

3. Ashifa .KM (2020). Human rights Awareness and Advocacy role of Youth : An Empirical Analysis, Rupkatha Journal on Interdisciplinary Studies in Humanities(ISSN: 0975 2935, Volume-12, Issue- 1, 2020, https://dx.doi.org /10.21659/ rupkatha.v12n1.27

4. Ashifa K.M, "Human Rights Awareness among Engineering Graduation Students". Journal of Advanced Research in Dynamical and Control Systems, 11 (special issue 12), 596-598, 2019.

5. Ashifa KM (2020). Life Skill Innovative Practices Among Automobile Industries" published with PalArch's Journal of Archaeology of Egypt/ Egytology,17(6); pp 1010110110; http://www.palarch.nl/index.php/jae/article/view/2575

6. Ashifa KM (2020). Occupational Burnout and Stress among Nurses in Private Hospitals in India".Annals of the Romanian Society for Cell Biology; 24(2); http://www .annalsofrscb.ro /index.php/journal/article/view/42

7. Ashifa KM. (2020). Effect of substanance abuse on physical health of Adolescents" published with European Journal of Molecular \& Clinical Medicine ( ISSN : 2515-8260; 7(2); https://ejmcm.com/article_2537.html

8. Ashifa KM. (2020) .Effect of substanance abuse on physical health of Adolescents" published with European Journal of Molecular \& Clinical Medicine ( ISSN : 2515-8260; 7(2); https://ejmcm.com/article_2537.html

9. Cole, M, "Education, Equality, and Human Rights". Routledge,2006.

10. Deibert, R, "Cyberspace Under Siege. Vol. 26" California: Johns Hopkins University Press,2015.

11. Donders, Y., Mcgonalge, T, "The United Nations and Freedom of Expression and Information". [pdf] Available at: <http://assets.cam bridge.org/97811 070/83868/frontmatter/9781107083868 _frontmatter.pdf> [Accessed 7 June 2016], 2015.

12. Dustin, "Human Rights Fact-Finding and the Reproduction of Hierarchies", in Human Rights FactFinding in the 21st Century, ed. by Philip Alston and Sarah Knuckey, Oxford University Press,2010.

13. Guo .C and Gregory D. Saxton, "Tweeting Social Change How Social Media Are Changing Nonprofit Advocacy", Nonprofit and Voluntary Sector Quarterly, 43, 57-79, 2014.

14. Herman,J, "Hashtags and Human Rights: Activism in the Age of Twitter", Carnegie Council for Ethics in International Affairs, 2014.

15. K.M.Ashifa.\& KS Swapna (2020). Performance Appraisal Model Of Resource Teachers In Inclusive Class Rooms: A Structural Analysis, Advances in Mathematics: Scientific Journal, ISSN:1857-8438, 9(9) https://research publication.com/amsj /all-issues/vol-9-no-9-2020/

16. McPherson. E. "Digital Human Rights Reporting by Civilian Witnesses: Surmounting the Verification Barrier", in Producing Theory in a Digital World 2.0: The Intersection of Audiences and Production in Contemporary Theory, ed Rebecca Ann Lind. New York, NY: Peter Lang Publishing, II, 193-209,2015

17. OHCHR. "The International Bill of Human Rights". Retrieved from www.ohchr.org: https://www.ohchr.org/Documents/Publications/Compilation1.1en.pdf. 
18. Olivier De Schutter, "International Human Rights" , edX, <www.edx.org/course/ international-humanrights-louvainx-louv2 $x>2015$.

19. Plowden, P., \& Kerrigan, K, "Advocacy and Human rights: Using the convention in courts and tribunals", Cavendish, 2002.

20. R.A. Rasi , KM Ashifa, Tariq Elhadary\& Ms. JeslinAnto (2020)Emotions of Young Adults on Crime Reports against Women" published with PalArch's Journal of Archaeology of Egypt/ Egytology( ISSN : 1567-214x; 17(6); pp 10111-10121; http://www.palarch.nl/index.php/jae/article/view/2576)

21. Ramya P.\&Ashifa K.M(2020).A Study on Stress Management among Sales Women in Textile Industry . International Journal of Advanced Science and Technology , 29 (6s). http://sersc.or g/journals /index.php/ IJAST/article /view/11077 ).

22. Rasi.RA and Ashifa KM. (2020) Supporting The Disabled: The Leading Role Of Non Governmental Organizations In India” published with European Journal of Molecular \& Clinical Medicine ,7(2); https://ejmcm.com/article_2539.html

23. Thrall .T., "May We Have Your Attention Please? Human-Rights NGOs and the Problem of Global Communication", The International Journal of Press/Politics, 19, 135-59,2015

24. Youth for Human Rights International, 'Youth for Human Rights Online Education App", Youth for Human Rights Online Education, 2015, <http://education. youthforhumanrights .org/edutranslated.html>. 